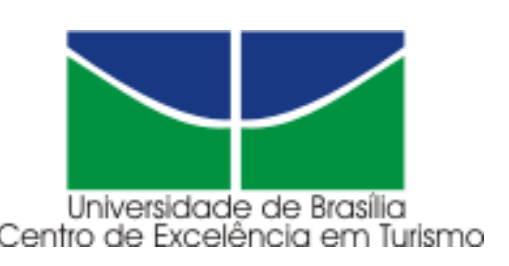

UNIVERSIDADE DE BRASÍLIA - UnB

CENTRO DE EXCELÊNCIA EM TURISMO - CET

BRASÍLIA: OFERTA DE TURISMO E LAZER PARA O PÚBLICO GLBT - GAYS, LÉSBICAS, BISSEXUAIS E TRANSEXUAIS

SANDRA ALVES DE OLIVEIRA

Brasília / DF de março de 2004. 


\author{
UNIVERSIDADE DE BRASÍLIA - UnB \\ CENTRO DE EXCELÊNCIA EM TURISMO - CET \\ CURSO DE ESPECIALIZAÇÃO GESTÃO E MARKETING DO TURISMO
}

\title{
BRASÍLIA: OFERTA DE TURISMO E LAZER PARA O PÚBLICO GLBT - GAYS, LÉSBICAS, BISSEXUAIS E TRANSEXUAIS
}

\section{Sandra Alves de Oliveira}

\author{
Dra. Deis Lucy Siqueira \\ Orientadora
}

\begin{abstract}
Monografia apresentada ao Centro de Excelência em Turismo da Universidade de Brasília como requisito parcial para a obtenção do Certificado de Especialista em Gestão e Marketing do Turismo.
\end{abstract}

Brasília /DF de março de 2004. 
Oliveira, Sandra A.

BRASÍLIA: OFERTA DE TURISMO E LAZER PARA O PÚBLICO GLBT - GAYS, LÉSBICAS, BISSEXUAIS E TRANSEXUAIS.

Brasília: UnB/CET, 2004

P. 59

Especialista em Gestão e Marketing do Turismo - Universidade de Brasília, Centro de Excelência em Turismo, 2004.

1. Turismo 2. Lazer 3. Segmentacão 4. GLBT 
Sandra Alves de Oliveira

Banca Examinadora

Professor X

Professor $Y$ 


\section{DEDICATÓRIA}

Dedico esse trabalho a cada uma das pessoas entrevistadas que colaboraram com o enriquecimento pessoal que obtive, durante as horas em que passamos juntos. E, a todos que são excluídos e segregados pela ignorância alheia. 


\section{AGRADECIMENTOS}

À Doutora Deis Siqueira, minha orientadora, pelo incentivo ao desenvolvimento do trabalho.

Ao Professor Domingos Spezia, coordenador do curso de Gestão e Marketing do Turismo -V, por todo o apoio e por ter acreditado na viabilidade desse estudo.

À minha família, pelo carinho e compreensão.

À minha amiga Fernanda Matos, pelo apoio e amizade. 


\section{EPÍGRAFE}

"Cada um sabe a dor e a delícia de ser o que é".

Caetano Veloso 


\section{RESUMO}

Com o objetivo de elencar a oferta de lazer e turismo para o público GLBT em Brasília foi que participei de algumas reuniões com grupo de lésbicas e gays, para constatar a satisfação e ou insatisfação quanto ao que já existe. Foi percebido quão carente se faz esse segmento de infra-estruturas adequadas às suas especificidades para sentirem-se seguros e à vontade, longe de olhares preconceituosos e críticos.

O segmento GLBT é um imenso potencial a ser explorado. Com planejamento, criatividade, parcerias, persistência e trabalho será possível superar os mais diversos desafios para se consolidar como uma boa perspectiva de retorno financeiro.

Ficam registradas neste trabalho as informações, concedidas por algumas pessoas, de que há uma significativa carência de produtos voltados exclusivamente para esse nicho de mercado que cresce a cada dia. 


\begin{abstract}
With the purpose of analyzing the supply of leisure and tourism opportunities specifically targeted at the gay and lesbian public in Brasilia, I participated in meetings with representatives of these groups. My expectation was to hear about their satisfaction and/or dissatisfaction with the existing services. I learned that there is a significant shortage of infrastructure and proper services targeted at them, which prevents them from feeling safe, comfortable, and protected against criticism and prejudice.
\end{abstract}

The gay and lesbian public has an immense potential to be explored. With planning, creativity, partnerships, persistence, and hard work it will be possible to overcome the various challenges and consolidate this segment as one with highest perspectives of good financial return.

This monograph compiles information provided by key people confirming the existence of a lack of products targeted exclusively to this portion of the market, which as a matter of fact is in expansion. 


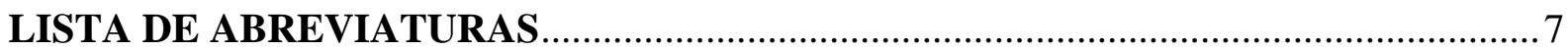

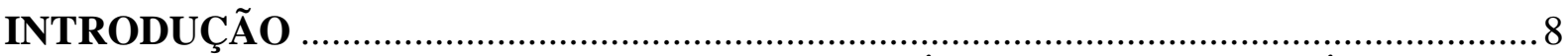

1. TURISMO, LAZER E HOSPITALIDADE AO PÚBLICO DE GAYS, LÉSBICAS,

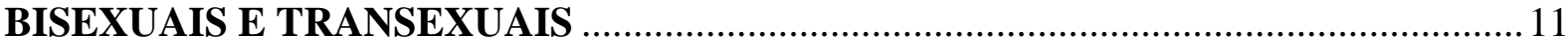

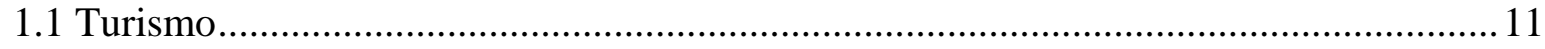

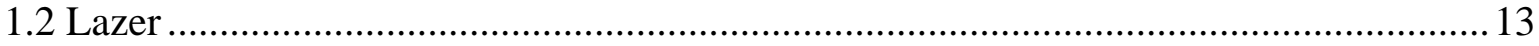

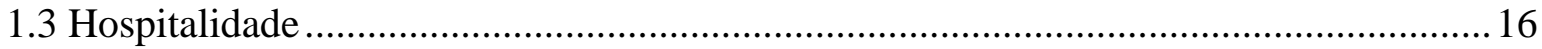

1.4 Qualidade na Prestação dos Serviços - Definições........................................................ 17

2. PERFIL DOS PROFISSIONAIS NO MERCADO DE TRABALHO DO TURISMO 20

3. MARKETING APLICADO AO MERCADO TURÍSTICO ....................................... 22

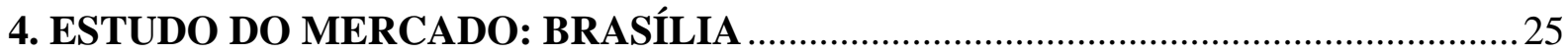

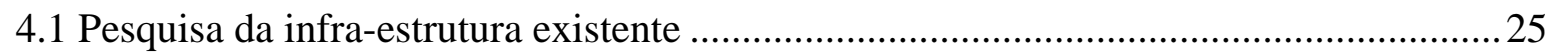

5. CONCEITOS, DEFINIÇÕES E DIREITOS DO PÚBLICO ALVO ...........................26

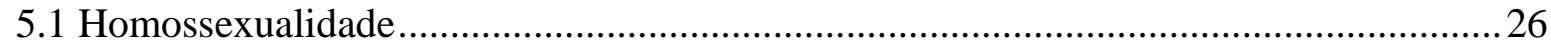

5.2 Princípio da Igualdade - Discriminação por orientação sexual ....................................... 30

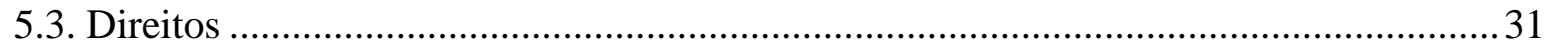

6. METODOLOGIA, FONTE DE DADOS E RESULTADOS DA PESQUISA .............. 35

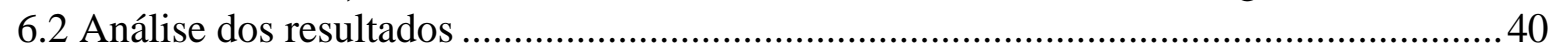

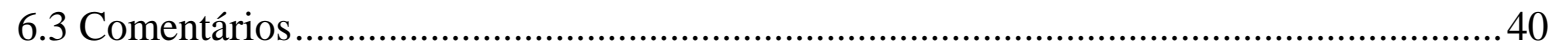

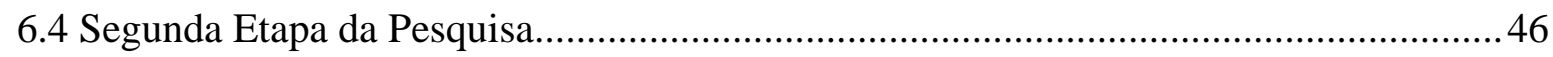

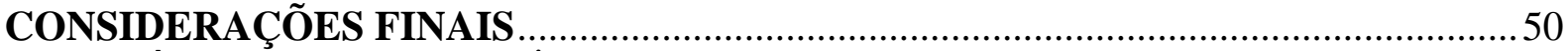

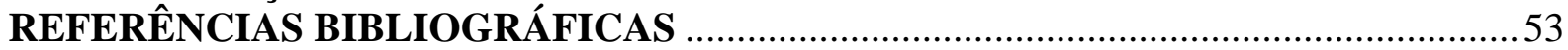

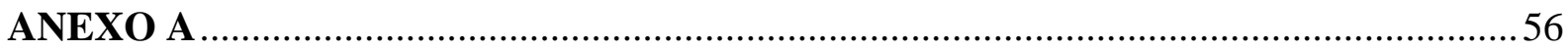

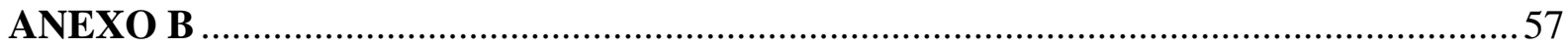

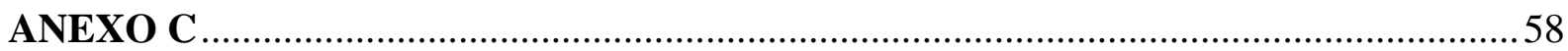

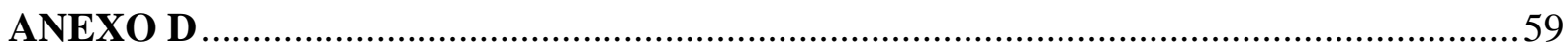

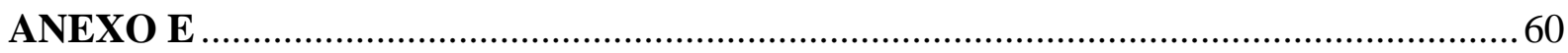

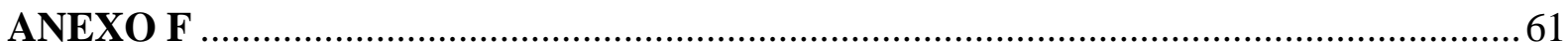




\section{LISTA DE ABREVIATURAS}

ISO - International Organization for Standasrdization, organismo internacional de padronização, com sede em Genebra

OMT - Organização Mundial do Turismo

GLBT - Gays, Lésbicas, Bissexuais e Transexuais

SENAC - Serviço Nacional de Aprendizagem do Comércio

SEBRAE - Serviço Brasileiro de Apoio às Micro e Pequenas Empresas

ONG - Organização Não Governamental

Embratur - Instituto Brasileiro de Turismo

SECHOSC - Sindicato dos Empregados no Comércio Hoteleiro, Restaurantes, Bares e Similares do DF

DF - Distrito Federal

TV - Televisão

DST - Doenças Sexualmente Transmissíveis

AIDS - Acquired Immune Deficiency Syndrome 


\section{INTRODUÇÃO}

Brasília: oferta de turismo e lazer para o público GLBT - Gays, Lésbicas, Bissexuais e Transexuais.

O público homossexual brasileiro representa 16 milhões de pessoas, porém esse nicho de mercado só começou a ser explorado no Brasil há pouco mais de cinco anos. Nos Estados Unidos esse mercado movimenta anualmente US\$ 50 bilhões. (Central de reservas de hotéis www.hdn.com.br).

Segundo entrevista feita por esta pesquisadora, com o Sr. Welton Trindade, Presidente da ONG Estruturação, o público abordado possui uma renda superior em relação à média dos heterossexuais, por investirem demasiadamente na vida profissional e não terem família com que dividir a renda. Portanto, têm liberdade para desfrutar do turismo e do lazer durante todo o ano. São, no geral, turistas bem informados e decididos sobre o destino e atrações que desejam visitar. Priorizam o conforto e a comodidade na hora de planejar seu lazer.

A partir desse pressuposto, verifica-se o quanto é pertinente o investimento no turismo para esse segmento. Estudos para quantificar a satisfação do cliente GLBT são de fundamental relevância para a otimização do produto Brasília, onde se verifica uma grande demanda. O objeto deste estudo é avaliar as estruturas de lazer e turismo que Brasília tem a oferecer para esse segmento de mercado.

Em fases destas preocupações, surgiram as seguintes questões:

- Quais as opções de lazer e turismo oferecidas em Brasília para o público GLBT locais e turistas?

- Por que é importante a avaliação das estruturas de lazer e turismo para o público GLBT? A oferta satisfaz a demanda?

- Por que é necessária a segmentação de opções de lazer e turismo para o público GLBT? 
- Qual a importância de traçar o eixo, segundo o qual, os profissionais de turismo devem se posicionar na adequação e construção da infra-estrutura e dos serviços para a captação deste segmento de mercado?

Segundo o Relatório Kinsey (2003), o público GLBT representa cerca de 10\% da população mundial. É um público crescente e com alto poder aquisitivo. Ciente disso é que o Brasil está investindo abertamente na chamada "indústria rosa".

Brasília não é unicamente a capital política do país. É, igualmente, um centro de idéias, de militância política, de cultura e lazer. Nesse contexto, pode-se inserir um mercado de convivência homossexual. Portanto, é preciso estudar a estrutura de lazer e turismo que Brasília oferece para o público GLBT e sua satisfação qualitativa, proporcionando a criação e adequação de infra-estrutura e serviços condizentes com as exigências deste segmento.

Obter-se-ão, ao término deste trabalho, resultados que podem contribuir para viabilização a adequação das exigências de um público segmentado que quer infra-estrutura e atendimento privativo, correspondendo às suas expectativas para não sofrer nenhum tipo de constrangimento ou preconceito ou amenizar tais manifestações.

O objetivo deste trabalho é estudar a estrutura de lazer e turismo que Brasília oferece para o público GLBT e sua satisfação qualitativa, proporcionando a criação e adequação de infraestrutura e serviços condizentes com as exigências deste segmento.

Os objetivos específicos deste trabalho são:

- Demonstrar a importância da população GLBT no mercado do turismo. Durante o decorrer do texto, esse público será chamado genericamente de homossexuais.

- Traçar a existência de estabelecimentos e serviços direcionados a esse segmento em Brasília.

- Identificar através de questionários a satisfação do homossexual com relação aos estabelecimentos e serviços destinados a ele.

- Traçar como os profissionais de turismo devem se posicionar na construção e adequação da infra-estrutura e dos serviços para a captação deste segmento de mercado. 
Serão levantados, no capítulo 1, os principais conceitos em turismo, lazer e hospitalidade, qualidade na prestação de serviços para a área de turismo e hospitalidade, cruzando-os com as particularidades do público GLBT.

O capítulo 2 mostra o perfil do profissional no mercado de trabalho da área de turismo e hospitalidade e a oferta de qualificação profissional existente.

No capítulo 3, apresentam-se os conceitos de marketing e sua utilização no setor de turismo.

O capitulo 4 menciona o estudo de mercado Brasília e a infra-estrutura de lazer existente para o atendimento do público.

O capítulo 5 mostra as definições, direitos e princípios do público GLBT, e,

Por fim o capítulo 6 demonstra os dados e resultados dessa pesquisa. 


\section{TURISMO, LAZER E HOSPITALIDADE AO PÚBLICO DE GAYS, LÉSBICAS, BISEXUAIS E TRANSEXUAIS}

\subsection{Turismo}

De acordo com Krapt apud OMT (2001 p.37), em uma definição de 1942, o turismo foi considerado como a soma de fenômenos e de relações que surgem das viagens e das estâncias dos não residentes, desde que não estejam ligados a uma residência permanente nem a uma atividade remunerada.

Atualmente, está descrito na OMT (2001 p.38), que o turismo compreende as atividades que realizam as pessoas durante suas viagens e estadas em lugares diferentes ao seu entorno habitual, por um período consecutivo inferior a um ano, com a finalidade de lazer, negócios ou outros.

O turismo é um fenômeno caracterizado pela interação de pessoas com diferença de idade, sexo, renda, educação, raça e religião, classe social, culturais e sócio econômicas, realizando trocas de experiências através do contato que se dá por meio do atendimento entre os diversos serviços disponíveis no setor de turismo e lazer.

É de grande relevância a segmentação de mercado para o turismo, para o atendimento das diferentes necessidades que são encontradas no mercado mundial para serem atendidas e satisfeitas.

Para o turismo, essas variáveis de segmentação são fatores importantes no momento de ofertar um produto no mercado uma vez que, quanto mais focados no específico, mais provavelmente satisfarão às suas necessidades. Observa-se que há uma particularidade no mercado turístico; por exemplo: um produto ofertado para pessoas de sexualidade com características gay é automaticamente excludente para outros mercados. Isso considerando apenas uma variável que é o sexo, sem considerar raça, religião a classe social. (MOTA, 2001 p. 67) 
O turismo brasileiro tem grande importância para a economia. De acordo com a Embratur, é o responsável direto por 4\% do PIB Nacional, situa-se entre as atividades econômicas que mais cresce no país, gerando emprego e renda para a população. Ocupa a $3^{\mathrm{a}}$ posição entre os produtos que mais geram receitas internacionais, contribuindo decisivamente para o equilíbrio da balança comercial.

Esse crescimento da atividade turística no País acontece devido aos investimentos no setor tanto por parte do governo, dos empresários, mas principalmente das pessoas que fazem essa atividade acontecer, ou seja, os clientes dos produtos e serviços turísticos, pois é o aumento da demanda turística que gera os resultados dessa atividade.

Segundo Oliveira (2001 p.44), o turismo é a atividade econômica que mais se desenvolve no mundo, gera consumos, origina rendas, e cria mercados nos quais a oferta e a procura se encontram.

O turismo brasileiro gera milhares de empregos e promove o desenvolvimento.Várias economias mundiais se sustentam essencialmente nessa atividade. No Brasil, pretende-se aumentar o fluxo interno de turistas e potencializar a marca "Brasil - um país de todos", no exterior.

Para o desenvolvimento desse trabalho, o público em potencial aqui estudado é o GLBT, que apresenta características distintas em sua conduta e necessidades diferenciadas para seu atendimento. É necessário estar preparado para atender essa demanda que é exigente, possui alto poder aquisitivo, bom gosto, requinte e entre seus hábitos freqüentes, o lazer e turismo.

O turismo GLTB cresce e rende milhões no país. São consumidores em potencial, na maioria das vezes, sem filhos e sem gastos tradicionais com a família. Até pouco tempo, esse nicho de mercado tinha poucas opções de lazer e turismo. Atualmente já se encontram alguns lugares preparados para atender essa demanda. 


\subsection{Lazer}

De acordo com Cavalcanti (1983 p.4), o lazer é uma construção ideológica, sob a qual o antilazer se aproveita para penetrar mais eficazmente no modo de vida das pessoas, com o objetivo de mantê-las integradas na sociedade. A rotina de trabalho e estudos leva o indivíduo a busca de divertimento, como forma de fugir das pressões e de integrar-se socialmente. Tudo que se busca em momentos de lazer é a total liberdade de expressão.

Ou, no dizer de Pascal (1961 p.72) lazer é como o ruído que nos desvia de pensar na nossa condição e nos diverte.

A seguir o conceito de lazer por Marcellino:

Fenômeno gerado historicamente e do qual emergem valores questionadores da sociedade como um todo, e sobre o qual são exercidas influências da estrutura social vigente. Assim, a admissão da importância do lazer na vida moderna significa considerá-lo como um tempo privilegiado para a vivência de valores que contribuam para mudanças de ordem moral e cultural. Mudanças necessárias para a implantação de uma nova ordem social.

(MARCELLINO, 1987 p.40)

Ainda segundo Marcellino (1987 p.31), o lazer é uma atividade de escolha individual, praticada no tempo disponível e que proporcione determinados efeitos, como o descanso físico ou mental, o divertimento e o desenvolvimento da personalidade e da sociabilidade. E o caráter desinteressado dessa vivência, não se busca, pelo menos fundamentalmente, outra recompensa além da satisfação provocada pela situação. A satisfação é proporcionada, sobretudo pela hospitalidade em cada ambiente.

A oferta de lazer envolve profissionais de diferentes setores da sociedade. E é de fundamental importância que todos os atores sociais que disponibilizam no mercado opções de lazer para a sociedade, estejam adequadamente qualificados para atenderem as diversas demandas sem preconceitos ou discriminações. 
O lazer pode proporcionar a integração do homem ao grupo. Facilita a comunicação em clima de espontaneidade e alegria, favorece o encontro entre pessoas diferentes e colabora nas relações humanas.

Seja qual for a maneira pela qual é utilizado o lazer implica sempre na universalidade do anseio por tempo livre, liberdade de opção da forma de ocupá-lo, poder de absorção das ocupações escolhidas e a possibilidade de auto-afirmação nas atividades desinteressadamente cultivadas. (MEDEIROS, 1975 p. 117)

A liberdade de escolha por lazer independe da orientação sexual, portanto os empreendedores que investem em infra-estruturas de lazer, turismo, entretenimento e outras precisam estar abertos para esse público e preparados para o seu atendimento. Os empresários devem buscar profissionais qualificados para elaboração de seu plano de negócio, que precisa ser bem definido e estar condizente com a realidade, procurando atender as necessidades do público que se pretende atingir.

Para atender as necessidades do público alvo é muito importante pensar em qualificação profissional, pois se faz necessário preparar a mão-de-obra que irá interagir diretamente com as pessoas e, especialmente nesse caso, é relevante para que todos tenham suas expectativas satisfeitas.

Serão citadas algumas das propostas da Carta ao Lazer defendida por Medeiros, com as quais se concorda. (1975 p.118):

- o lazer é aquele espaço não comprometido de tempo do qual o homem pode dispor livremente, fora das horas de trabalho e das obrigações da vida diária;

- o aspecto mais sério do lazer é a liberdade que oferece ao indivíduo, ao qual permite experimentar-se, exprimir-se, conhecer-se, até, superar-se;

- bem aproveitada, tal liberdade lhe facilita ser melhor como homem, como profissional e como elemento produtivo da sociedade; 
- as atividades de lazer podem servir à integração social dos indivíduos, porque se desenrolam em clima de alegria e participação voluntária. Ao canalizarem tensões e descargas da agressividade, contribuem para reduzir as transgressões da ordem social, funcionando como válvulas de segurança da sociedade;

- como o aproveitamento do lazer é livre, respeitadas as limitações de desenvolvimento pessoal e ordem social, cabe aos que respondem pelo bem-estar coletivo oferecer condições materiais que estimulem uma utilização positiva das horas livres. Compete-lhes planejar, criar e ajudar a manter ambientes agradáveis e estéticos, além de acomodações e instalações variadas, de modo a facilitar a cada pessoa fazer escolhas acertadas de ocupações do lazer, segundo seu gosto e sob a própria responsabilidade, tendo plena consciência das possibilidades ao seu alcance.

No que diz respeito ao segmento constituído pelo GLBT, Isac Bonfim, declara que:

Atualmente, os mais significativos empreendimentos voltados ao público GLBT estão no segmento de lazer, tais como bares, boates, saunas etc, face ao retorno garantido e rápido dos investimentos. Contudo, é preciso observar que se os movimentos homossexuais conseguirem vitórias em todas as suas instâncias, emancipando realmente ao grupo que representam, muitos desses empreendimentos estarão fadados ao fracasso; afinal, os homossexuais libertos sentirse-ão seguros a freqüentar qualquer tipo de ambiente, não sendo necessário confinar-se em guetos. .

(BONFIM apud. ESTUDOS TURÍSTICOS 2003)

O ideal para a prestação de serviços, em ambientes destinados ao turismo e ao lazer, é possibilitar aos freqüentadores um clima de uma interação produtiva, em convívio de respeito e aceitação. 


\subsection{Hospitalidade}

O bem receber é imprescindível para que o público GLBT sinta-se seguro e confortável. Portanto, serão abordados alguns conceitos de hospitalidade como se segue.

De acordo com Butle apud OMT (1986 p.23), hospitalidade é o conjunto de satisfações e insatisfações pelo qual o cliente recebe a experiência da hospitalidade. As satisfações devem ser:

- fisiológica (sede, calor, sono);

- econômica (valor do dinheiro, crédito);

- $\quad$ social (companhia, serviço);

- psicológica (auto-estima, status, segurança).

Beger apud OMT (1984 p.23), considera hospitalidade como oferecer segurança às pessoas, considerando conforto físico e psicológico em troca de pagamento.

Ter um bom atendimento e a sensação gratificante de ser bem vindo, proporciona elevado grau de conforto e segurança. Pagar um preço justo pelos serviços ofertados se os mesmos satisfazem as expectativas não é motivo de contrariedade; pelo contrário, de satisfação e prazer.

Beger apud OMT (1984 p.24), cita alguns elementos integrais que são característicos da hospitalidade, tais como:

- a combinação complexa de benéficos e aspectos tangíveis e intangíveis;

- interação satisfatória entre serviço e prestador, consumidor e hóspede;

- segurança, conforto psicológico, fisiológico, com alimentação, bebida e acomodação;

- a hospitalidade pode ser lucrativa ou não.

Conforme a OMT, somente após a II Guerra Mundial é que os cursos de gerenciamento em hospitalidade surgiram na América do Norte. Na Europa existem desde 1883 na L'École Hotelerie de Lausanne, demonstrando portanto uma grande tradição na área de receber bem. 
O Brasil é por si só considerado um país hospitaleiro. Atrai turistas de todo os lugares pela diversidade e beleza natural e pela alegria do povo. No entanto, no que diz respeito a uma qualificação específica e técnica, ainda há muito que se fazer.

E para que haja qualidade do atendimento, faz-se necessário que os empreendedores e gestores do setor turístico repensem suas estratégias de serviços, oferecendo aos profissionais oportunidades de formação técnica.

Conforme Trigueiro, (1999 p.57) a motivação para o lazer e turismo vem do atendimento às necessidades das pessoas. Afinal, se as pessoas têm satisfeitas suas expectativas, elas retornam várias vezes e ainda fazem uma divulgação positiva, aumentando a demanda do local visitado.

Durante as entrevistas realizadas por esta pesquisadora com o segmento GLBT, diversas vezes foi mencionado pelos entrevistados a deficiência no atendimento e serviços prestados pelos lugares voltados ao público. Há falta de preparo, no que diz respeito a qualificação profissional e até mesmo no treinamento básico de funcionários para o atendimento específico aos casais homossexuais.

\subsection{Qualidade na Prestação dos Serviços - Definições}

Não se pode deixar de mencionar a qualidade no atendimento e serviços porque o consumidor tem buscado cada vez mais lugares voltados para o bom atendimento. Segue, portanto, algumas definições de qualidade.

De acordo com Albrecht (1993) apud ZIMENEZ (1999 p.42), qualidade é uma medida da extensão até a qual uma coisa ou experiência satisfaz uma necessidade, resolve um problema ou adiciona valor para alguém.

Harovitz (1993) apud Zimenez (1999 p.42), introduz a idéia de excelência ao termo qualidade, afirmando que é o nível de excelência que a empresa escolheu alcançar para satisfazer à sua clientela-alvo. É, ao mesmo tempo, a medida com que ela se conforma a esse nível. 
De acordo com Zimenez (1999 p.43), a qualidade não significa a melhor performance, mas sim a performance especificada para responder a uma determinada necessidade. Ou seja, cada produto atendendo a um público e adequando-se às suas especificidades.

Uma definição que pode ser mencionada é a adotada na terminologia da ISO, onde a qualidade é definida como "a totalidade de uma entidade que lhe confere a capacidade de satisfazer as necessidades explícitas e implícitas". Dentro disto, pode-se encontrar algumas definições específicas, que serão descritas abaixo, quanto a:

- Política de Qualidade - intenções e diretrizes globais de uma organização relativa à qualidade formalmente expressa pela administração;

- Gestão de Qualidade - parte da função gerencial global que concretiza e implementa a política da qualidade;

- Garantia de Qualidade - todas as ações planejadas e sistemáticas necessárias para prover confiança de que um produto ou serviço atenda aos requisitos definidos da qualidade;

- Controle da Qualidade - técnicas operacionais e atividades utilizadas para verificar e atender aos requisitos da qualidade;

- Sistema da Qualidade - conjunto de normas, procedimentos técnicos e recursos utilizados pela gestão da qualidade;

- Plano de Qualidade - conjunto de atividades a serem realizadas num determinado espaço de tempo com responsabilidade para um determinado produto ou contrato.

De acordo com Anderson \& Zemke apud Zimenez (1999 p.45), a partir de meados da década de 80, observadores profissionais de negócios começaram a notar um elemento importante, para não dizer surpreendente, na linha de frente da prestação de serviços. Descobriram que algumas organizações que tinham se dedicado a fornecer a seus clientes serviços de qualidade superior estavam atingindo melhores resultados. Essas organizações cresceram mais rápido (mesmo que na maior parte do tempo cobrassem mais por seus produtos e serviços) e tornaram-se mais rentáveis do que as empresas que trabalhavam duro para dar a seus clientes o mínimo possível. Em resumo, as empresas que valorizavam o fornecimento de serviços estavam começando a ganhar mais dinheiro do que as que não o faziam. 
Investimento em qualidade dos produtos e serviços prestados é o que cada empresa deve buscar para ter o cliente satisfeito quanto às suas necessidades e expectativas, para que os empregados tenham prazer no trabalho desenvolvido, sintam-se motivados e que tenham perspectiva de carreira, para que os empresários tenham retorno sobre os investimentos realizados e para que os fornecedores e sub-fornecedores possam ter continuidade nos negócios. São vários os setores interligados que usufruem dos benefícios de uma gestão competente e responsável.

Uma organização voltada para os serviços deve ter a mania de conhecer os clientes, sem desistir nunca de querer saber tudo o que puder sobre eles. Ter a mania de ouvi-los permanentemente e sempre agir a partir daquilo que eles disserem.

(ALBRECHT e BRADFORD apud ZIMENEZ 1999 p.62) 


\section{PERFIL DOS PROFISSIONAIS NO MERCADO DE TRABALHO DO TURISMO}

Através de pesquisas realizadas pelo Instituto de Hospitalidade (2001 p.31), na atividade turística do Brasil constata-se que:

- há mais homens (56\%), que mulheres (44,2\%) no mercado de trabalho do turismo. Somente em hotéis e pousadas as ocupações são tipicamente femininas;

- nos bares e restaurantes a situação é relativamente equilibrada, sendo a participação masculina $53,4 \%$ e a feminina, $46,6 \%$;

- a idade média do trabalhador no setor de turismo é de 35,2 anos;

- quanto à escolaridade do trabalhador no setor de turismo, há bastante variabilidade. O maior nível educacional encontra-se nas agências de turismo, onde constata-se o nível de $2^{\circ}$ grau. Em seguida os profissionais da área de lazer e entretenimento com um nível de $1^{\circ}$ grau e os demais sem a conclusão completa do mesmo;

- entre as diferentes regiões do país observa-se uma variação no nível de escolaridade dos trabalhadores. As regiões Sul e Sudeste têm resultados mais favoráveis do que Norte e Nordeste. As demais regiões ficam em situação intermediária;

- e quanto à remuneração, os desníveis regionais acompanham as diferenças de escolaridade;

- os profissionais das áreas de bares e restaurantes estão abaixo da média salarial dos profissionais da área de agências, de hotéis e pousadas.

Em se tratando da oferta de qualificação profissional no Brasil de acordo com a LDB existe:

- a Educação Profissional, que integrada às diferentes formas de educação, ao trabalho, à ciência e à tecnologia, conduz ao permanente desenvolvimento de aptidões para a vida produtiva e pode acontecer através do oferecimento de Cursos Básicos - destinado a qualificação de trabalhadores e estudantes sem a exigência de escolaridade prévia; Cursos Técnicos - destinados a proporcionar habilitação profissional a alunos matriculados ou egressos do ensino médio ou concomitante a ele e Cursos Tecnológicos - correspondem a cursos de nível superior na área tecnológica, destinados a egressos do ensino médio e técnico. 
- a Educação Superior têm como objetivo estimular a criação cultural e o desenvolvimento do espírito científico e do pensamento reflexivo, incentivar o trabalho de pesquisa e investigação, promover a divulgação de conhecimentos culturais, científicos e técnicos. A Educação Superior se dá através de Cursos de Graduação, Pós-Graduação (lato e stricto sensu).

Os Cursos de Educação Profissional normalmente são oferecidos em Instituições Públicas e Privadas ou pelo sistema S (Senac, Sebrae e Senai) e os Cursos de Educação Superior são oferecidos em Universidades públicas e privadas.

Em parceria com o SENAC e SEBRAE, o Programa Brasil Empreendedor Turismo está desenvolvendo Projeto de Capacitação Itinerante que visa o aperfeiçoamento dos empreendedores e profissionais, com atendimento prioritário aos municípios contemplados nos corredores turísticos.

De acordo com Ansarah (2002 p.83/87) existem no Brasil 339 cursos de bacharelado em Turismo e Hotelaria e 300 Instituições educacionais que oferecem esses cursos. Pode-se verificar que a oferta de qualificação profissional no Brasil é bem ampla, contudo essa oferta não está atendendo às necessidades de formação que o mercado deseja, devido a multidisciplinariedade da área de Turismo e Hospitalidade e as confusões decorrentes da estruturação de seus currículos.

De acordo com a Embratur (2001 p.65), são metas do Governo Federal a melhoria de infraestrutura nos potenciais pólos turísticos e a valorização dos programas de capacitação profissional do setor; isso mostra que o governo está preocupado com desenvolvimento do turismo no Brasil, sendo que a qualificação profissional é fator fundamental para que isso aconteça. 


\section{MARKETING APLICADO AO MERCADO TURÍSTICO}

De acordo com a Embratur (2001 p.48), nos últimos anos o perfil do turista, seja nacional ou estrangeiro, alterou-se em vários aspectos fundamentais, gerando novos projetos e ações estimuladas. Novas modalidades de turismo acrescentaram-se às consideradas tradicionais e centenas de novos pontos e pólos de lazer e consumo surgiram em todo o Brasil. Houve uma espetacular multiplicação de atrativos, renda e empregos.

Segmentos como $3^{\text {a }}$ idade, ecoturismo, turismo religioso, turismo GLBT são mercados identificados para proporcionar melhor atendimento, de acordo com as especificidades de cada um, e conseqüentemente, melhor qualidade de vida e lazer ao cidadão.

Chegar ao público GLTB não é tarefa fácil, pois não se observa em jornais, TV, rádios e revistas, anúncios exclusivos para esse segmento. Verifica-se contudo uma grande divulgação desses espaços em sites gays, revistas e jornais regionais, organizados pelo próprio público, porém a propaganda é feita sobretudo de "boca a boca".

Nas entrevistas realizadas por esta pesquisadora constatou-se que se os lugares são definitivamente assumidos como "bar, boate ou restaurante gay", o público acaba se direcionando para tal ambiente, prestigiando inclusive os empreendedores, que muitas vezes são também. É uma forma de divulgar e valorizar aquilo que foi desenvolvido exclusivamente para essa clientela. Foi mencionado também, que pode se fazer boicote quando se sentem desprestigiados.

Para se ter uma idéia sobre a importância do marketing para o desenvolvimento de um empreendimento de turismo ou lazer, serão abordados alguns conceitos importantes sobre mercado, segmentação e planejamento estratégico.

Segundo a definição de Mota (2001 p.61), mercado consiste em um conjunto de pessoas que compartilham de uma necessidade ou desejo específico, dispostos e habilitados a realizar transações de troca que satisfaçam a sua necessidade. 
Para Tabares apud Mota (1991 p.26), a consolidação de um mercado não consiste somente em sustentar as correntes turísticas atuais, mas também em incrementar o mercado com sólidas políticas mercadológicas.

De acordo com Mota (2001 p.65), os mercados são constituídos de compradores que diferem em desejos e necessidades de acordo com o meio em que vivem, com a cultura, poder aquisitivo, localização geográfica e classe social, dentre outros. Esses mercados podem ser fragmentados em segmentos, nichos ou indivíduo.

Há vários mercados potenciais para atender a demanda do produto turístico. (Beni apud Mota, 1998 p.24). É necessário conhecer o consumidor, seus hábitos e preferências, para melhor satisfazê-lo. A segmentação possibilita a identificação de grupos homogêneos, conhecimento da demanda real e potencial, influencia a estrutura da oferta, melhora a relação custobenefício dos esforços de marketing, atenua a sazonalidade e eleva o padrão de atendimento ao consumidor superando as suas expectativas. É importante saber o que produzir, como produzir e para quem produzir.

O marketing turístico oferece roteiro através de um planejamento estratégico para consolidação de empresas no setor. E para se entender o que é planejamento estratégico, citaremos a seguir alguns conceitos.

De acordo com Kotler e Armstrong (1995 p.3), planejamento estratégico é o:

processo de desenvolvimento e manutenção de uma referência estratégica entre os objetivos e capacidades da empresa e as mudanças de suas oportunidades no mercado: é a base de planejamento de uma empresa e depende do desenvolvimento de uma missão clara para a empresa, da definição de objetivos , de um portfólio de negócios e da coordenação de estratégias.

(KOTLER E ARMSTRONG, 1995 p.3) 
Conforme Mota (2001 p.122), uma estratégia de marketing pode ser entendida como um programa geral da empresa para selecionar um mercado - alvo específico e satisfazer seus consumidores, mediante um cuidadoso equilíbrio dos elementos do composto de marketing produto, preço, distribuição e promoção - que representam subconjuntos da estratégia geral de marketing.

O marketing é uma das principais ferramentas para a administração de uma empresa. Pois a partir dele é possível atingir o principal objetivo que é a satisfação do cliente e conseqüentemente a rentabilidade promissora da empresa. E uma das estratégias dos empreendedores para a expansão e consolidação no mercado de turismo e lazer deve ser a oferta de lugares com bom preço, qualidade de serviços, criatividade e identidade que os diferenciem dos outros. 


\section{ESTUDO DO MERCADO: BRASÍLIA}

Inaugurada em 1960, a capital do Brasil é a única cidade do século XX considerada Patrimônio Cultural da Humanidade. Moderna e cosmopolita, Brasília é uma mistura das mais diversas culturas do Brasil e do mundo. Mais que uma cidade, Brasília é um lugar surpreendente e com brilho próprio.

O traço criativo de Lúcio Costa, a arquitetura de curvas de Oscar Niemeyer e a obstinação de Juscelino Kubitschek, fez de Brasília a capital de cada brasileiro, imersa num grande céu de azul profundo, a cidade é generosa e solidária abrigando a todos que vêm das mais diversas regiões, oportunizando qualidade de vida.

Uma homenagem criativa a essa cidade futurista, feita pela Revista A Capital do Séc.XXI:

Brasília não é uma cidade mulher como o Rio de Janeiro, Paris, Roma ou Veneza. Não é também uma cidade masculina, a exemplo de São Paulo, Londres, Nova Iorque, Berlim ou Chicago. É uma cidade de todos os brasileiros, madura, poética, fusão de trabalho, poder e lazer. Uma cidade substantiva quanto aos negócios, edêmica quanto aos prazeres do lazer e presente se o tema é o respeito aos direitos da cidadania.

(REVISTA BRASÍLIA A CAPITAL DO SÉCULO 21 p. 33)

\subsection{Pesquisa da infra-estrutura existente}

De acordo com SECHOSC - Sindicato dos Empregados no Comércio Hoteleiro de Restaurantes, Bares e Similares em Brasília há aproximadamente quatro mil empresas voltadas ao público em geral. 


\section{CONCEITOS, DEFINIÇÕES E DIREITOS DO PÚBLICO ALVO}

\subsection{Homossexualidade}

Para a melhor compreensão da elaboração deste estudo se fazem necessários alguns conceitos. Segundo Sturbrin, (1998 p. 66), ser homossexual significa que o objeto do desejo de um sujeito é uma pessoa de seu mesmo sexo, e que suas relações e fantasias sexuais são fundamente com pessoas de seu mesmo sexo.

De acordo com o Dicionário Eletrônico HOUAISS (2001), homossexual é o relacionamento sexual mantido por indivíduos do mesmo sexo. Que denota homossexualidade. Que ou aquele que sente atração sexual e/ou mantém relação amorosa e/ou sexual com indivíduo do mesmo sexo.

Conforme Ramires (2003 p. 2), a sociedade brasileira vem se dando conta de que existe um contingente imenso de pessoas que amam de forma diferente, fora do padrão heterossexual dominante. Faz vir à tona que apesar de sermos todos iguais em dignidade e cidadania, isto é, termos todos os mesmos direitos, cada um de nós realiza em sua vida uma trajetória peculiar que deve ser respeitada

Para maior compreensão do termo GLBT (Gays, Lésbicas, Bissexuais e Transexuais) será apontada algumas características de relevância desses segmentos, segundo o Guia de Prevenção DST/AIDS.

- Gays - Termo utilizado para definir homossexuais masculinos no geral, é o termo universal preferido pelos homossexuais do mundo inteiro.

- Lésbicas - Não se constitui um grupo homogêneo, uniforme, com as mesmas características. São mulheres que se sentem atraídas por outras mulheres em diferentes momentos da sua vida.

- Bissexuais - Homens que se relacionam com mulheres e homens e mulheres que se relacionam com homens e mulheres. 
- Transexuais - Tem como característica principal o desejo constante e intenso de modificar seu sexo genital. Entende-se que uma pessoa transexual possui a genitália de determinado sexo (masculino ou feminino), porém sua psique é oposta a ele.

A intenção deste trabalho não é ficar discutindo a homossexualidade, ter direitos, entre outros, mas apontar a satisfação ou insatisfação quanto ao lazer ofertado em Brasília ao público GLBT. Portanto, apenas para enriquecer um pouco o assunto, foi buscado na tese "A Reinvenção do Corpo”, da Dra Berenice Bento (2003), algumas informações a respeito de gênero e subjetividade, como se verá a seguir.

De acordo com Bordieu apud Bento (2003 p. 93), a construção da identidade de gênero é um processo de longa e ininterrupta duração. O indivíduo não reconstrói diariamente sua visão do mundo, nem mesmo sua forma de agir sobre ele. Ao contrário, ele traz em si, por um processo de inculcação (ou "interiorização da exteriorização"), um "sistema de disposição durável", (porque não foi produzido pelo indivíduo, é anterior a ele), um habitus, que funciona praticamente como uma bússola, determinando as "condutas razoáveis ou absurdas para qualquer agente" inserido em uma estrutura. Este é o princípio norteador da percepção e da apreciação de toda experiência posterior. São matrizes geradoras de sentido. E, no caso dos gêneros, uma das matrizes que dará inteligibilidade e sentido será a heterossexualidade. E a partir dessa matriz que se justificam e se constroem corpos como entidades diferentes.

Aqui o autor explica a maneira pela qual o agente incorpora uma personalidade singular, como podemos ver a seguir:

O habitus permite ao ator adaptar-se a situações concretas. A prática do agente social é o produto da relação dialética entre uma situação e um habitus. No momento do agir, o agente social exterioriza uma "leitura" própria (fruto da interiorização da exteriorização) da situação vivida, tornando-o ao mesmo tempo um indivíduo portador de uma personalidade singular e de um habitus social, contribuindo para construir uma situação.

Ainda de acordo com Bento (2003 p.94), os sistemas de disposições individuais são variantes estruturais do habitus social que o indivíduo reestrutura no confronto com outros habitus. Quando se fala de performances de gênero e na capacidade do agente atuar interpretando as normas, se está afirmando que os sujeitos têm margens de interpretação e que há espaços para 
produção de contra-discursos e fissuras na ordem de gênero. Esse seria talvez o princípio organizador das subjetividades. O habitus social é a matriz, mas há também os sistemas de suposições individuais, adquiridos por constantes reestruturações ou ajustamentos, variando de acordo com as situações. O grau de desvio que o indivíduo porta em relação à matriz geradora varia. É no espaço do "desvio" que se localizam as subjetividades. Daí Bordieu considerar que as ações dos indivíduos podem assumir o caráter de ações coordenadas, ainda que não totalmente, pois são resultado do encontro de diferentes habitus, sendo este o princípio da socialização.

O corpo é uma situação histórica, uma maneira de ir fazendo-se, tornando-se, dramatizando e reproduzindo uma situação histórica que o gera, o torna real, que o corporifica. A corporização manifesta claramente um conjunto de estratégias materializadas em uma estilística da existência que nunca se auto-estiliza totalmente, pois é dada pelas condições históricas que limitam suas possibilidades.

Para Figueira apud Bento (2003 p.96), a subjetividade refere-se ao nível imaginário, às emoções, às fantasias, aos desejos, aos medos pertencentes a cada sujeito.

De acordo com Guia de Prevenção das DST/aids e Cidadania para Homossexuais (ano p.128), a Homossexualidade no Brasil não é crime, nem o Código Penal, nem a Constituição Federal proíbem o sexo entre pessoas do mesmo sexo, maiores de 18 anos. E já existem leis estaduais e municipais que proíbem o preconceito e a discriminação por orientação sexual. Em 1990, Salvador foi a primeira cidade da América Latina a proibir discriminação por orientação sexual na Lei Orgânica Municipal, seguida de mais 72 municípios e nas Constituições de Sergipe e Mato Grosso.

Para Almeida e Crillanovick (2001 p.170), os homossexuais vivem seus cotidianos como soldados em um campo de guerra: permanentemente envolvidos em conflitos - seja através da ocultação de seus desejos, seja através do enfrentamento deliberado do olhar e da fala de acusadores do outro.

Não se pode entender porque a sociedade coloca-se numa condição "julgadora", quando em todas as áreas, nota-se situações conflitantes de poligamias, incesto, prostituição, tráficos e consumos de drogas, os crimes de "colarinho branco", crimes passionais e tantos outros. 
Pesquisadores demonstram que a sociedade é homofóbica, ou seja, há uma particularidade na discriminação existente contra os homossexuais. E o que motiva o crime ou o preconceito, muitas vezes, é a rejeição pura e simples da pessoa em razão de sua orientação sexual. Há uma tendência dominante a que o homem que opta por ser gay, travesti, transexual ou a mulher que opta por ser lésbica, são vistos como pessoas desequilibradas, desajustadas e doentes, que precisam ser excluídas da convivência em sociedade. Contudo, se a sociedade resolver excluir todos os grupos tidos como anormais, acabará por se auto-excluir e aniquilar, pois a mesma demonstra incoerências no comportamento.

A sexualidade ancora-se na diferença, operacionalizada num conjunto de marcas sociais que posicionam um sujeito num determinado mundo de relações sociais. A marca da cultura produziu e impôs o reconhecimento valorativo na heterossexualidade como marca e limite da diferença, numa sociedade androcêntrica. A diferença aqui se produz não pelo exercício da alteridade, isto é, não a partir da concepção da particularidade do ente/ser. A diferença se dá via e pela compreensão, isto é, pela oposição-negação. A compreensão não invoca o ser. Apenas o nomeia e assim comete a seu respeito, ao mesmo tempo, uma violência e uma negação. Nesse sentido, a diferença (re) produz novas diferenças, reforçando o valor, as normas institucionalizadas e autoritárias, que privilegiam a heterossexualidade que fracassa em reconhecer a alteridade, a diferença na e pela homossexualidade, gerando violência e ódio, que acentuam as cisões. No caso de gays e lésbicas e outras diferenças possíveis, o movimento polar-pendular da diferença imobiliza-se de forma absoluta no marginal e estes ficam sujeitos à vergonha , à discriminação e à violência.

(SIQUEIRA e BANDEIRA, 2001 p.121)

Não se ignora que a homossexualidade vem de datas remotas da antiguidade. Desde que o homem existe as trocas entre os mesmos sexos sempre existiram. Não querer tirar o véu da ignorância remete a sociedade a uma condição de hipocrisia. A discriminação seja ela qual for, impossibilita a convivência harmoniosa, trazendo conseqüências para todos. 


\subsection{Princípio da Igualdade - Discriminação por orientação sexual}

De acordo com Golin e Weiler (2002 p.24/25), o princípio da igualdade no direito brasileiro abrange as dimensões formal e material, além de expressamente adotar critérios proibitivos de diferenciação. O rol destes critérios proibitivos de diferenciação tem sua sede principal no artigo $3^{\circ}$, inciso IV, da Constituição da República, onde se estabelece a vedação de diferenciação por motivo de origem, raça, sexo, cor, idade e quaisquer outras formas de discriminação.

O autor salienta que as proibições de discriminação por este ou por aquele critério são entendidas como apelo e recordação de fatores que freqüentemente são utilizados como pretextos injustificados de discriminação, o que não exclui a interdição de outras diferenciações arbitrárias. Deste modo, a ausência de expressa previsão do critério orientação sexual não é obstáculo para seu reconhecimento, não bastasse a explícita abertura constitucional para hipóteses não arroladas explicitamente no texto normativo.

A discriminação por orientação sexual é uma hipótese de diferenciação fundada no sexo da pessoa para quem alguém dirige seu envolvimento sexual, na medida em que a caracterização de uma ou outra orientação sexual resulta da combinação dos sexos das pessoas envolvidas na relação. Assim, conforme o autor relata, Pedro sofrerá ou não discriminação por orientação sexual precisamente em virtude do sexo da pessoa para quem dirigir seu desejo ou sua conduta sexual. Se orientar-se para Paulo, experimentará a discriminação; todavia, se dirigirse para Maria, não sofrerá tal diferenciação. Os diferentes tratamentos, neste contexto, têm sua razão de ser no sexo de Paulo (igual ao de Pedro) ou de Maria (oposto ao de Pedro). Este exemplo ilustra com clareza como a discriminação por orientação sexual retrata uma hipótese de discriminação por motivo de sexo.

Contra este pensamento, pode-se objetar que a proteção constitucional em face da discriminação sexual não alcança a orientação sexual; que a discriminação não se define pelo sexo de Paulo ou Maria, mas pela coincidência sexual entre os partícipes da relação sexual, tanto que homens ou mulheres, nesta situação, são igualmente discriminados. Este argumento não subsiste a um exame mais apurado, porque é impossível a definição da orientação sexual sem a consideração do sexo dos envolvidos na relação verificada; ao contrário, é essencial para a caracterização de uma ou de outra orientação sexual levar-se em conta o sexo, tanto 
que o sexo de Paulo ou de Maria é que ensejará ou não o juízo discriminatório diante de Pedro. Ou seja, o sexo da pessoa envolvida em relação ao sexo de Pedro é que vai qualificar a orientação sexual como causa de eventual tratamento diferenciado.

De acordo como o autor, justificar a discriminação contra homossexuais pelo fato de tanto gays quanto lésbicas serem atingidos não enfrenta a proibição de discriminação por motivo de sexo, na medida em que, tanto numa hipótese quanto noutra, o sexo dos envolvidos é fator decisivo para a diferenciação. A proibição de discriminação por motivo de sexo compreende tanto homens quanto mulheres, alcançando as relações estabelecidas por quaisquer dos dois sexos, sejam heterossexuais ou homossexuais.

Contudo, de acordo com as reflexões do autor, constata-se que a dimensão formal do princípio da igualdade seja, em sua enunciação geral, seja nos seus desdobramentos concretos, veda a diferenciação e estabelece a equiparação entre heterossexualidade e homossexualidade nas questões jurídicas. Disto decorre um imperativo absoluto de equiparação entre heterossexuais e homossexuais, sendo descabidas, em qualquer hipótese, as diferenciações.

A discriminação por orientação sexual é uma das realidades que mais fortemente resiste e desafia o mandamento de igualdade.

\subsection{Direitos}

O respeito à individualidade é assegurado constitucionalmente e as providências cabíveis para coibir o desrespeito contra o próximo estão sendo tomadas. O Seminário de Direitos Humanos e Cidadania Homossexual, promovido pela Comissão de Direitos Humanos da Câmara dos Deputados, em 21 de setembro de 1999, teve como objetivo encontrar alternativas para o combate à crescente violência contra os homossexuais. Contando com vários grupos de organizações não-governamentais representativas dos segmentos homossexuais da população homossexual foi discutido e exposto, através de relatos vivenciados, toda a luta contra a discriminação sofrida. Estiveram presentes no seminário, entre outros expositores, a exDeputada Marta Suplicy, e o representante da Rede Nacional de Direitos Humanos, Raldo Bonifácio.

A seguir a descrição da justificativa dada pelo então Deputado Miranda (2000 p.65/66): 
- os homossexuais na sociedade brasileira sofrem todo tipo de discriminação e preconceito, representando hoje um dos setores mais vitimizados. As estatísticas demonstram que cresce o número de crimes contra os homossexuais como assassinatos, tortura, maustratos, lesões corporais etc. Também são numerosos os casos de ação de grupos de extermínio e de violência policial contra essas pessoas. As cidades que registram maior número de violações são Rio de Janeiro, Salvador, São Paulo e Goiânia;

- a violação mais comum aos homossexuais é a discriminação e o preconceito que acontecem cotidianamente nos locais públicos e instituições. Recentemente, foi instalado no Rio de Janeiro um disque-denúncia de violações contra os homossexuais, registrando cerca de 60 denúncias de discriminação por dia, somente nos primeiros dias de funcionamento. Os gays, lésbicas, travestis e transexuais enfrentam humilhações, intolerância, e os mais diversos preconceitos. Porém, quando chegam a denunciar tais condutas nada é feito pelas instituições judiciárias. Na própria delegacia de polícia essas ações delituosas, quando registradas, sequer são averiguadas, sob a alegação de que não há o tipo penal de discriminação por orientação sexual. Assim não originam inquéritos nem mesmo ação penal;

- a Constituição Federal dispõe sobre a garantia do princípio da dignidade da pessoa humana, um dos fundamentos da República Federativa do Brasil. Há também dispositivos que asseguram o direito à intimidade e à vida privada. No entanto, é mister que se tenha no ordenamento jurídico a previsão para a discriminação por orientação sexual, da mesma forma que já existe essa conduta tipificada como delituosa para o racismo;

- no dia 21 de setembro de 1999 foi realizado na Comissão de Direitos Humanos desta Casa Legislativa um seminário com a presença de diversas entidades de defesa dos direitos humanos dos homossexuais. Após um dia inteiro de debate com juristas e deputados, ficou deliberado que esta Comissão ingressaria com um projeto de lei tipificando o crime de discriminação por orientação sexual. Optamos, assim, em alterar a Lei $n^{0} 7.716 / 89$, que define os crimes resultantes de preconceito de raça ou de cor, ao invés de criar nova lei ordinária para a tipificação penal de preconceito por orientação sexual, uma vez que há grande semelhança nas condutas discriminatórias. 
Miranda conclui que "em face do exposto, conclamo os nobres colegas a apoiarem a presente iniciativa, na certeza de que estarão contribuindo para acabar com a discriminação e o preconceito contra os homossexuais”.

O Congresso Nacional decreta:

Art. $1^{\circ}$ da Lei $\mathrm{n}^{0} 7.716$, de 1989, alterado pela Lei $\mathrm{n}^{\circ}$ 9.459, de 1997, passa a vigorar com a seguinte redação:

Art. $1^{\circ}$ Serão punidos na forma desta lei, os crimes resultantes de discriminação ou preconceitos de raça, cor, etnia, religião, procedência nacional ou orientação sexual.

Em alguns sites gays há informações sobre o direito de ser homossexual, tais como o abaixo descrito:

Não há citação, na legislação brasileira, contra a homossexualidade. Ao contrário, ilegal é a discriminação, pois segundo nossa constituição, somos todos iguais. Além disso, há 73 leis orgânicas de municípios (inclusive em Natal/RN) e 3 constituições estaduais que proíbem a discriminação por orientação sexual.

( www.rnmix.hpg.ig.com.br/canais/direito/leinatal.htm , 2004)

Os direitos civis são importantes para a comunidade homossexual porque em muitas circunstâncias os homossexuais não têm os mesmos direitos essenciais que os outros cidadãos do seu país. Um indivíduo homossexual pode, de forma perfeitamente legal, ver banido o seu acesso a casa, emprego e serviços públicos apenas devido à sua orientação sexual.

Artigo $3^{\circ}$ - constituem objetivos fundamentais da República Federativa do Brasil.

I - Construir uma sociedade livre, justa e solidária

II - Garantir o desenvolvimento nacional.

III - Erradicar a pobreza e a marginalização e reduzir as desigualdades sociais e regionais.

IV -Promover o bem de todos, sem preconceitos de origem, raça, sexo, cor, idade, e quaisquer outras formas de discriminação. 
Artigo $5^{\circ}$ - O "artigo $5^{0 "}$ da Constituição Federal do Brasil reforça os princípios contidos na legislação internacional de proteção aos Direitos Humanos. Todos são iguais perante a lei, sem distinção de qualquer natureza, garantindo-se aos brasileiros e aos estrangeiros residentes no país a inviolabilidade do direito à vida, à liberdade, à igualdade, à segurança e à propriedade.

Lei 152/98 "Lei Olegário Passos" Promulgada em 19/05/0998.D.O.20/05/0998

Artigo $1^{\mathrm{o}}$ - Fica proibida toda e qualquer discriminação por motivo de raça, credo ou orientação sexual em espaços públicos e estabelecimentos comerciais, no âmbito do município do Natal.

Parágrafo único. Entende-se como discriminação todo e qualquer processo seletivo que envolva práticas de maus tratos, sejam físicos ou morais, proibições de acesso a estabelecimentos ou espaços públicos, e toda medida que venha tolher o direito de ir e vir do cidadão, por motivo de raça, crença ou orientação sexual.

Conforme Siqueira e Bandeira (2001 p.112), uma sociedade igualitária, fundada no mérito pessoal e na defesa dos direitos individuais, há muito deixou de ser unânime e está hoje recoberta por outra promessa que a contradiz e a ela se contrapõe, que é a de promover os grupos desfavorecidos.

Cada vez mais se pode perceber que o direito à diferença tende ou à aceitação plena ou à exclusão absoluta do outro, caracterizando-se como um novo imaginário político e cultural Como ainda existe discriminação e preconceito é importante que discuta-se fatos relevantes como a liberdade de expressão, de opção sexual e tantos outros temas de igual importância.

Não só o desejo homossexual vai deixando o gueto e expandindo suas fronteiras, como as pessoas homossexuais se apossam cada vez mais do seu desejo e se transformam em seus próprios porta-vozes políticos. Ou seja, ser homossexual aponta, cada vez mais, para a sua forma pessoal de ser militante, o que significa que a militância se investirá de tantas formas quantas forem as pessoas desejantes.

(TREVISAM apud GOLIN E WEILER, 2002 p.190). 


\section{METODOLOGIA, FONTE DE DADOS E RESULTADOS DA PESQUISA}

A investigação teve início entre os meses de outubro/2003 a fevereiro de 2004. Foi elaborada através de pesquisa bibliográfica, na Biblioteca do Centro de Excelência em Turismo - UnB, Biblioteca Central da UnB, na rede Mundial de computadores, em pesquisas de campo, através de entrevistas semi-dirigidas com questionário ao público GLBT na Organização NãoGovernamental - Estruturação e nos bares, com os proprietários e funcionários. Esta pesquisa foi realizada no Plano Piloto e foi aplicado em torno de cinqüenta questionários aos participantes das reuniões e a seis proprietários de estabelecimentos. O número reduzido, quanto aos donos desses estabelecimentos, se dá devido a grande dificuldade que se tem em encontrar os proprietários e dos demais funcionários não sentirem-se seguros em dar as entrevistas. Logo no início do trabalho foi percebido que não seria fácil entrevistar os consumidores nos bares devido ao respeito que se deve à privacidade no momento de lazer compartilhado entre os parceiros e amigos. Por isso que foi feita a visita a ONG Estruturação e pedido permissão para participar das reuniões e aplicar a entrevista.

A pesquisa ora realizada procurou demonstrar a oferta de turismo e lazer para o público GLBT, suas preferências e o grau de satisfação em relação aos mesmos. Buscou-se definir conceitos importantes para o entendimento desse tema. Antes, porém, serão feitas algumas abordagens sobre a ONG Estruturação, através de entrevista feita com o Sr Márcio Koshaka, pelo Sr. Walter Júnior:

Melhorar a qualidade de vida de gays, lésbicas e travestis é a missão do Estruturação - Grupo Homossexual de Brasília. Em 2004, o grupo completa dez anos de luta contra o preconceito, por meio do incentivo do pleno exercício da cidadania e fortalecimento da auto estima de homossexuais.

O Brasil seria o campeão mundial de assassinatos a homossexuais, segundo uma pesquisa realizada pelo Grupo Homossexual da Bahia. Foram 126 homicídios em 2002 e mais de dois mil, nos últimos vinte anos. No Distrito Federal, são comuns casos de ofensas e até mesmo de violência, sobretudo, no Parque da Cidade Sarah Kubitschek. O Estruturação está atento a esses acontecimentos. "Monitoramos as investigações e, além disso, vamos fazer um dia de mobilização contra a homofobia. Será uma manifestação pelo fim da violência como um todo, 
seja homossexual ou não, indigna-se Márcio Koshaka, diretor de planejamento estratégico da ONG.

Essa violência, discutida nos meios de comunicação, está relacionada ao preconceito, à dificuldade que algumas pessoas ainda têm de respeitar as diferenças. Segundo Márcio, esse preconceito tem suas raízes na moral judaico-cristã, que prega dogmas fechados: o homem foi feito para mulher, sexo é somente para procriação, fidelidade aos princípios cristãos. Pedro,(nome fictício) estudante universitário de 25 anos, é homossexual e veio para Brasília depois que decidiu contar aos pais cariocas. "Eles são evangélicos e não aceitam até hoje minha orientação sexual”, revela o estudante. Muitas vezes o preconceito aparece dentro de casa, e esses são os casos mais complicados.

O Estruturação tem uma média de 400 pessoas cadastradas e a maioria na faixa etária dos 17 aos 21 anos. Grande parte desses jovens vivem situações parecidas com a de Pedro. Pensando nisso, o grupo tem um projeto para reunir filhos homossexuais a seus pais e parentes.

Todo esse medo e a preocupação de um dia ser descoberto torna-se um agravante não só psicológico, como físico, pois já existem estatísticas que confirmam que dentro desse segmento, a Aids cresce mais em pessoas que vivem em conflito com relação à sua homossexualidade. Geralmente, são pessoas que vivem em isolamento, na solidão e quando o desejo aparece, elas vivem situações de perigo para se satisfazerem, esquecem do uso do preservativo e procuram locais mais perigosos, tudo isso por uma questão de falta de identidade.

Segundo Pedro, para mudar a situação "vulnerável” que o homossexual vive hoje, somente com o fim do preconceito. “Estamos suscetíveis à discriminação, à violência”, resume o estudante. O Estruturação sempre busca políticas públicas para dar maior proteção aos homossexuais. Campanhas, protestos, manifestações, fazem parte da rotina desta ONG. O ato de maior repercussão do grupo aconteceu no ano de 2002, quando o presidente do grupo, Welton Trindade, entregou uma bandeira do movimento gay ao ex-presidente Fernando Henrique Cardoso, durante a cerimônia de lançamento do Programa Nacional de Direitos Humanos.Violência, preconceito, discriminação, respeito, igualdade, DST/Aids, são temas discutidos nas reuniões do Estruturação, que acontecem todas as terças-feiras às 19:30h. 


\subsection{Primeira Etapa da Pesquisa}

A pesquisa foi realizada em duas reuniões, na ONG Estruturação, sendo uma com todo o grupo GLBT, que acontece às terças-feiras a partir das 19 horas e outra com um grupo de lésbicas, que ocorre às quartas-feiras às $19 \mathrm{~h} 30$ além de várias visitas aos bares mencionados pelo próprio público GLBT, como os mais freqüentados por este segmento. A idade dos participantes variou entre 18 anos a 36 anos. Exceção a apenas uma participante de 16 anos.

Após conversa desta pesquisadora com as participantes lésbicas, foi constatado que:

- em sua maioria preferem receber as amigas e namoradas em casa;

- gostam de jogar baralho, assistir filmes, e quando o clima colabora, preferem ir ao Parque da Cidade para jogar futebol e voley;

- organizam piqueniques e churrascos;

- os encontros são mistos, tendo a participação de gays, lésbicas e heterossexuais.

Uma das opções de lazer para os finais de semana é a locação em vídeo-locadoras de filmes do gênero, conforme abaixo relacionados.

- Desejo Proibido - com Sharon Stone

- Ligadas Pelo Desejo

- Eclipse De Uma Paixão - Com Leonardo Di Caprio

- $\quad$ Aimee \& Jaguar

- Madame Satã

- Quando a Noite Cai

- Paixão Selvagem, dentre outros.

Quanto aos lugares, listados pela ONG Estruturação, as respostas foram bastante enriquecedoras, possibilitando a mensuração da satisfação do público GLBT, conforme abaixo especificado. 


\section{Bar do Barulho:}

Local: Parque da Cidade

Funcionamento: Quinta e domingo das 19h à 01hora.

Acesso: Livre e lotado aos domingos

\section{Bar Beirute:}

Local: CLS 109 Bloco A Loja 2/4

Funcionamento: Diariamente, das $11 \mathrm{~h}$ às $00 \mathrm{~h} 30$

Melhor dia GLBT é sexta depois das 21 horas

\section{Café Savana}

Local: CLN 116 Bloco A Loja 4

Funcionamento: Segunda a sábado a partir das $11 \mathrm{~h} 30$

ambiente descontraído para "bate papo" com cardápio refinado.

\section{Café Vyla Arena}

Local: Centro de Atividades 07 Bloco F1 - Loja 33 - Lago Norte

Funcionamento: Quinta-feira, sexta, sábado e domingo "matinê"

Bar com pista de dança - Público mais elitizado

\section{Reversão Café Musical}

Local: SCLN 206 Bloco C loja 15 A, Asa Norte

Bar de música ao vivo. ( Música Popular Brasileira )

\section{Cats Café}

Local: CLN 310 Bloco A

Bar com música ao vivo. (Música Popular Brasileira)

\section{Quo Vades Bar e Restaurante}

Local: CLN 309 -Subsolo

Oferece sábado cultural, com premiações para os participantes que acertarem as perguntas As músicas são tocadas em LP que são fornecidos em parte pelos freqüentadores. 


\section{Boate Garagem:}

Local:Setor de Oficinas Sul,Quadra 16 conjunto "A" Lote 5/6

Funcionamento: Sexta-feira , sábados e véspera de feriados das $23 \mathrm{~h}$ às 06 horas.

\section{Restaurante Universal:}

Local: $210 \mathrm{Sul}$

\section{Saunas:}

\section{- Thermas Soho}

Local: SCS Quadra 05 Bloco "A" Edifício Nicola Caminha Subsolo No 34

Ambiente direcionado apenas para o público masculino: Gays e garotos de programas

Aberto diariamente das $16 \mathrm{~h}$ às 23 horas.

- Thermas Acrópole Club

Local: Setor de Diversões Sul, Edifício Acrópole NN$^{\circ}$ 14- Loja 2 e 4 -Subsolo Ambiente só para o público masculino

Aberto diariamente das $14 \mathrm{~h}$ às 22 horas.

\section{- Thermas Três Chic}

Local: 713 Sul Bloco H, Casa 05 - Avenida W3 Sul

Ambiente só para público masculino

Aberto diariamente das $14 \mathrm{~h}$ às 22 horas

\section{Locais de Pegação}

- Profissionais do Sexo Masculino

Local: Setor de Diversões Sul, Estacionamento Frente ao CONIC

- $\quad$ Cine Ritz

Local: Setor de Diversões Sul, CONIC

- Estacionamentos do Parque da Cidade ( Do Alpinos ao Parque de Exposições )

Funcionamento: Diariamente, muito freqüentado à noite. 


\subsection{Análise dos resultados}

Após aplicar questionário (anexo 1), ao público GLBT, obteve-se resultados de acordo com a preferência de cada pessoa. Os lugares mencionados pelo público GLBT, se dá, principalmente, devido aos mesmos oferecerem de alguma maneira serviços mais voltados para o segmento, oportunizando o encontro entre todos. A lista abaixo, segue uma ordem de preferência.

$1^{\circ}$-Boite Garagem

$2^{\circ}$-Bar Beirute

$3^{\circ}$-Bar Barulho

$4^{\circ}$-Bar Quo Vadis

$5^{\circ}$ - Sauna Thermas Très Chic

$6^{\circ}$ - Café Vila Arena

$7^{\circ}$ - Sauna Thermas Soho

$7^{\circ}$-Café Savana

8'-Parque da Cidade - Pontos de "Pegação"

$9^{\circ}$-Restaurante Universal

10-Outros lugares não GLBT: Café Martinica

$11^{\circ}$ Outros lugares não GLBT: Belikatessen

Obs: A ordem sofre constantes alterações, devido aos processos naturais de modismos, sendo, portanto, a demanda sazonal. Foi constatada a empolgação de uma entrevistada divulgando de forma elogiosa uma das opções ofertadas para todo o grupo: o bar Quo Vadis, e logo em seguida várias pessoas demonstraram interesse em conhecer.

\subsection{Comentários}

A seguir alguns comentários relevantes de todos os itens que foram abordados durante as entrevistas feitas com o público GLBT quanto à satisfação, privacidade, atendimento, localização, preço e segurança. Serão citadas algumas respostas interessantes selecionadas e descritas na íntegra por esta pesquisadora.

- Privacidade que os lugares mencionados oferecem ao público GLBT 
Foi dito pelos entrevistados que praticamente não há privacidade por haver pessoas heterossexuais que freqüentam constantemente os lugares mencionados misturando-se ao público GLBT. Foi dito inclusive que a presença de heterossexuais acaba por inibir as demonstrações de carinho entre os parceiros do mesmo sexo. Algumas pessoas sentem-se mais a vontade à medida que vai ficando mais tarde e o local se esvazia permanecendo apenas o público GLBT. Portanto, Brasília ainda não oferece para essa demanda um lugar específico para esse segmento. A seguir alguns comentários dos próprios entrevistados.

De acordo com A. 30 anos "não existe privacidade em lugares como Barulho e Beirute, por serem lugares abertos. Na Garagem há muitos héteros, o que às vezes causa um certo "malestar"

Já de acordo com E. 23 anos, afirma que "depende da hora e do lugar".

- Quanto à satisfação do atendimento para o público GLBT.

Oberva-se que há uma insatisfação por parte do público GLBT quanto ao atendimento. Foi mencionado que há um certo amadorismo das pessoas que trabalham nesses setores e que muitas vezes é demonstrado um certo constrangimento por parte de quem está atendendo em verificar que o casal é homossexual e em outras circunstâncias constrangimento do próprio público, por sentir-se desrespeitado. Por unanimidade, em conversa com o público GLTB e esta pesquisadora, foi dito que não só nos estabelecimentos voltados para esse segmento, mas em outros lugares onde o atendimento é voltado para o público heterossexual também, o atendimento deixa muito a desejar.

De acordo com K. 24 anos, "não, têm lugares que tem um atendimento grosseiro".

L. 30 anos diz que "o atendimento em alguns lugares é precário, onde até os garçons dão em cima das mulheres, cantadas indiscretas e palavras vulgares".

- Quanto à localização dos lugares ofertados ao público GLBT. 
Foi dito que a localização de alguns lugares para o público GLBT é de difícil acesso, tendo-se muita dificuldade em chegar quando não está de carro. Quase sempre muitos deixam de freqüentar esses lugares por inviabilizar a volta para casa. Outros não reclamaram por estarem localizados nas entrequadras da Asa Sul e Asa Norte.

De acordo com M. 31 anos "faltam boates de melhor acesso para o GLBT."

P. 23anos e W. 22 anos, "o acesso pra boate é muito difícil e longe".

G. 18 anos, "Os lugares, muitas vezes, são escondidos".

- Quanto aos preços cobrados ao público GLBT.

Os entrevistados alegaram que, exatamente por serem identificados como GLBT, que têm fama de que é um público bastante exigente, acaba-se cobrando preços acima do que é cobrado em lugares mais convencionais. Uma minoria considera adequado e justo os valores cobrados.

De acordo com L. 29 anos "São altíssimos!"

E. 23 anos, "Sem comentários! Horrível".

A. 30 anos, "Caríssimo, tudo é bem mais caro em lugares GLTB".

A. 19 anos "Vale o preço cobrado".

- Quanto à segurança que os lugares oferecem ao público GLBT

Foi mencionada a falta de segurança em alguns lugares por não haver policiamento e iluminação pública. Houve relato inclusive de assalto que aconteceu altas horas da manhã, quando algumas pessoas saiam da boate Garagem, que fica numa localização de mais difícil acesso.

De acordo com K..., 30 anos "Lugares como o Barulho não tem policiamento nem iluminação". 
Y. 23 anos, "Pra que?? Em alguns lugares, os agressores são os proprietários".

L.H. 22 anos, "Não!!! Sinto-me inseguro".

- Quanto à importância de um ambiente e serviços desenvolvidos para atender apenas a grupos GLBT:

Demonstra-se nessa questão que a maioria dos entrevistados gostaria de ter um lugar com atendimento qualificado e específico para o público GLBT, onde pudessem sentir-se à vontade para expressar-se livremente através da troca de carinho com a pessoa amada e até ter a liberdade de poder trocar olhares, (paquerar),com os demais freqüentadores sem correr o risco de sofrer algum tipo de agressão. Foi mencionado também que a oferta de lugares para esse nicho de mercado é insuficiente, ocasionando muitas vezes uma evasão dos lugares freqüentados em busca de novidades.

De acordo com F. 24 anos "Sim. É muito importante que existam ambientes onde se tem a certeza de ser livre de preconceito".

J. 27 anos, "Sim. Pois é um público que encontra dificuldades para encontrar produtos, serviços e atendimento adequados no mercado não-direcionado".

W. 25 anos "Temos que ter lugares para nos expressar".

L. 20 anos "Sim, pois é um point de encontro onde pessoas que procuram a mesma coisa se sentem bem".

T. 20 anos, "Não. Prefiro lugares onde se mesclam os grupos".

L. 19 anos, "Importantíssimo. Em Brasília faltam lugares GLS. O público costuma freqüentar muito os únicos que existem até que enjoam e demoram um bom tempo até voltar".

C. 24 anos, "Não. Acho que o atendimento deve ser igual para todos mas na falta dessa igualdade não seria ruim um atendimento especializado". 
K. 24 anos, "Sim. Somos um público diferente, então precisamos e merecemos um atendimento específico. Talvez enquanto existir locais dedicados apenas a grupos heterossexuais, talvez deva ter locais só para GLBT".

S. 18 anos, "Acho sim, até porque em vários lugares héteros há, muitas vezes, pessoas preconceituosas, inclusive os próprios atendentes".

J. 27 anos, "Considero extremamente importante a existência de um ambiente que atenda satisfatoriamente gays, lésbicas, bissexuais e transexuais. Acredito que isso também é uma política afirmativa".

I. 26 anos, "Sim, até que todas a sociedade não tenha problemas em relacionar-se com pessoas diferentes como nós".

- Quanto ao público GLBT sentir-se discriminado em ambientes heterossexuais

Houve nesse quesito, uma demonstração de insatisfação quanto a forma de serem tratados porque além de não poderem expressar-se livremente, devido aos olhares preconceituosos, não são aceitos em alguns lugares, como foi mencionado abaixo por uma entrevistada.

D. 24 anos, "Algumas vezes sim, pizzarias com promoção para "casal", não aceitam casais homossexuais, por exemplo".

L. 19 anos, "Onde expresso carinho, sim. Inclusive comentários maldosos".

L.M. 29 anos, "Com certeza. Infelizmente ainda há muita discriminação".

W. 25 anos, "Sim. Mas sei exigir respeito".

F. 24 anos, "Sim, pela impossibilidade de expressar-me livremente".

- Quanto ao lugar ideal para o público GLBT:

Finalmente, quanto ao lugar ideal, foi mencionado pelos entrevistados a carência de um local específico para o público GLBT, onde estivesse presentes todos os fatores que geram 
satisfação, dentre os quais: segurança, conforto, diversidade cultural, preços justos, fácil acesso e qualidade no atendimento.

K 36 anos "O lugar que tivesse um espaço cultural, bons pratos com preços acessíveis e pessoas interessantes".

M. 24 anos, "Onde os funcionários e os donos não nos olhem apenas como produtos de investimento ou despreço".

L.16 anos "Um ambiente que tivesse pessoas do mesmo sexo".

W. 25 anos "Onde todos gays, ou não, fossem respeitados".

L. 29 anos, "Um lugar tranqüilo, seguro e com preços mais acessíveis".

D. 25 anos, "Um lugar só para lésbicas".

M. 31 anos, "Que funcionasse de dia também, eu gostaria que tivesse uma lanchonete ou outra qualquer".

K. 24 anos "Lugar com boa música ambiente, facilidade de pagamento com cartão de crédito, lugar seguro para estacionar e atendimento conscientemente preparado e dedicado ao público GLBT"

C. 27 anos, "Seria bonito, aconchegante, com preço acessível, localizado no centro, o atendimento também deve ser especializado e segurança, acredito, é necessária em qualquer lugar".

I. 26 anos, "Um lugar onde todos sem distinções convivessem em paz".

J. 27 anos, "Para me divertir? Um local onde o staff soubesse atender educada e adequadamente o público GLBT"

T. 20 anos, "Um lugar onde as pessoas não usem "máscaras" . 
A. 23 anos, "Onde todos soubessem e, respeitassem uns aos outros"

E. 23 anos, "Um lugar onde ninguém me perturbe, não cobre nem mais, nem menos. Justo e respeitoso".

Observa-se na pesquisa realizada com o público de GLBT que uma das principais reclamações quanto aos lugares ofertados em Brasília é a falta de serviços especializados. Portanto, verifica-se que esse segmento quer um atendimento diferenciado e especial, que atenda às suas necessidades de privacidade e conforto sem ser perturbado por olhares indiscretos de reprovação.

\subsection{Segunda Etapa da Pesquisa}

Após as reuniões feitas com o público GLBT, foram feitas visitas aos lugares mencionados pelos entrevistados com o objetivo de entrevistar os empresários para saber quais as características o segmento GLBT, se existe um marketing direcionado para o público alvo e quais as estratégias para o atendimento ao público GLBT.

As visitas foram feitas sexta-feira e sábado de fevereiro/2004, por volta das vinte e uma à 1 hora da manhã. Em primeiro lugar, foi constatado um número maior de mulheres presentes nestes estabelecimentos do que de homens. A priori, os lugares visitados foram:

Café Savana - uma casa que oferece um cardápio variado e de muito bom gosto. A comida extremamente saborosa e requintada. Os preços cobrados são considerados justos. Já existe há 12 anos. Notou-se uma clientela GLBT, de nível sócio-cultural mais elevada e um público misto presente.

A entrevista foi feita com o Encarregado do estabelecimento, (Sr. José Edvaldo). O proprietário Marcelo, não está presente.

Quanto às características do público GLBT, o Sr. Edvaldo respondeu que é um público bastante exigente quanto ao atendimento e à qualidade do que é servido. Por ser um lugar que recebe um público misto, as manifestações de carinho pelos casais homossexuais costumam acontecer em altas horas, quando grande parte das pessoas já foi embora. O marketing é feito 
através da Revista Sete - edição local e através do Caderno Brasília, do Jornal de Brasília. Mas, principalmente, a maior divulgação é feita através dos freqüentadores assíduos e satisfeitos.

Quanto ao atendimento ao público GLBT, o funcionário recebe orientação do próprio proprietário do estabelecimento para atender sem constrangimento e são encaminhados para cursos profissionalizantes de garçons.

Cat's Café - Bar com música ao vivo, bastante discreto. Foi observada a predominância de mulheres no ambiente. A casa já existe há 12 anos.

A entrevista foi feita com a proprietária Cristina, que adquiriu o ponto há pouco tempo e busca manter a identidade do lugar.

Quanto às características do segmento GLBT, mencionou que é um público altamente exigente e fiel. A freqüência é mista, com a predominância do GLBT. Embora discretos, sentem-se à vontade para namorar sem constrangimento. O marketing foi feito na Revista Veja no ano 2003 e está prevista para abril/2004 nova reportagem. É uma pesquisa voluntária da Revista Veja que menciona os estabelecimentos mais freqüentados em cada região. Contudo, considera que a maior propaganda é feita pelos freqüentadores de "boca em boca".

No que diz respeito à estratégia para o atendimento ao público GLBT, prefere contratar garçonetes por considerar que há preferência desse segmento em ser atendidos por mulheres. $\mathrm{Na}$ contratação da profissional, explica o serviço e orienta como comportar-se diante da clientela.

Quo Vades - Bar e Restaurante - Lugar bastante agradável, com diversidade cultural: música ao vivo, saraus e exposições culturais. Há opção dos clientes levar disco vinil para tocar. Não tem CD's. Cardápio variado e de bom gosto. Embora ambiente misto, observou-se a predominância de mulheres.

A entrevista foi feita com uma das proprietárias, Karla, que adquiriu o ponto em sociedade com a namorada, há 10 meses. 
Quanto à característica do público freqüentador, afirmou que o público GLTB se mistura com o heterossexual sem constrangimento. Tem uma clientela bastante exigente quanto aos serviços prestados. O marketing é aberto - feito através das exposições que acontecem no próprio ambiente atraindo o público e por ser jornalista, consegue divulgar através de jornais, DF/TV, sites gays, Agitador Cultural do DF,Guia "Boca a Boca” e outras revistas locais.

No que diz respeito ao atendimento para o público GLBT é feito praticamente pelas proprietárias e irmãs. No entanto, quando contrata alguém explica como proceder para não haver nenhum problema.

Café Arena - Funcionamento de quarta-feira a domingo das 18 às 01:h. Um sábado por mês é oferecido música ao vivo com bandas, voz e violão, dentre outros. Há predominância do público masculino na quinta-feira e de mulheres aos sábados. A casa existe há 2 anos.

A entrevista foi feita com o sub-gerente Adalton, o qual responde na ausência das proprietárias.

No que diz respeito à característica do público GLBT, afirmou que são de altíssimo nível sócio-cultural, bastante educados e exigentes. As manifestações de carinho e o namoro acontecem normalmente. Quanto ao marketing, a revista Veja Brasília publicou uma matéria divulgando o espaço, foi feita apresentação no Programa Alternativo da TV Bandeirante, divulgação através dos sites e revistas gays, além de propaganda "boca a boca".

A estratégia adotada pelas proprietárias no que diz respeito aos funcionários é a explicação do funcionamento da casa, deixando claro que público será atendido. A preferência na contratação é por pessoas sem experiência para que moldem-nas às exigências da casa para o atendimento diferenciado.

Restaurante Universal - Existe há 5 anos e não é mais destinado ao público GLBT. Recebe um público basicamente heterossexual, classe "A". Priscila, gerente da Casa, informou que no passado era mais específico para esse segmento de mercado, mas, atualmente trabalha com público heterossexual. 
Boate Garagem - Não foi possível realizar entrevista com o proprietário. No entanto foi feita por essa pesquisadora visita para avaliação da Casa.

Localizado no Setor de Oficinas Sul, próximo ao hiper mercado Carrefour. O público é predominantemente masculino com a eventual presença de lésbicas, travestis e heterossexuais. A casa divide-se em três ambientes: bar, pista de dança, “dark-room” (quarto escuro para "pegação” e contatos íntimos), área acima da pista de dança onde as pessoas ficam para descansar, conversar ou até paquerar. Tem ainda os chamados "gogo-boys" (dançarinos usando apenas mini-sungas) e, eventualmente, há shows com “drag queens”, ( homens travestidos de mulheres). O público GLBT de Brasília ou até os que vêm de outros estados em visita a cidade se fascinam com a qualidade do som e o efeito de luzes que a boate proporciona. A única reclamação é a falta de refrigeração e ventilação, ocasionando elevação da temperatura ambiente devido a grande quantidade de pessoas. Os preços são diferenciados de acordo com a atração da noite variando entre doze e trinta reais a entrada.

Beirute: Localizado na quadra 109 Sul, a administração da Casa não considera-se direcionada ao público GLBT, embora haja a predominância deste, após as 22 horas. Os clientes GLBT mantêm-se fiéis devido a oferta gastronômica variada, a localização e o atendimento eficiente e respeitoso dos garçons veteranos. É um “point” pré-boate ou “noitada”. Possui uma área superior para as pessoas que não querem ficar expostas independentes de serem ou não homossexuais.

Bar Barulho - Localizado no Parque da Cidade a freqüência do público GLBT, acontece a partir de quinta-feira, por volta das 17 às 23 horas ou mais dependendo do dia. É um espaço bastante popular. Foram feitas inúmeras visitas para conseguir entrevistar o responsável e não se obteve êxito. Os garçons não quiseram contribuir com as informações. Contudo, observouse que é um local de encontros , onde as pessoas reúnem-se para rever antigas amizades. Os preços são acessíveis, motivo pelo qual é bastante popular. O Castelinho, (construção de tijolos para lazer, no Parque da Cidade), que fica aproximadamente a uns trinta metros é utilizado para encontros íntimos ou“pegação”.

Reversão Café Musical - Foi feita a visita no endereço, porém o estabelecimento foi fechado. 


\section{CONSIDERAÇÕES FINAIS}

Apesar do público GLBT sempre existir o mercado do lazer e do turismo só começou a explorá-lo há cinco anos atrás, esta afirmativa conduz a uma reflexão: o porquê da importância do desenvolvimento de estruturas de lazer e turismo para o público GLBT e qual a sua satisfação quanto a esta oferta em Brasília.

Com a realização deste trabalho, pode-se considerar que após as visitas feitas por esta pesquisadora, em grande parte dos locais indicados, foi constatado que os lugares ofertados para o público GLBT, sobretudo os bares e cafés são ambientes aconchegantes e agradáveis que oferecem alimentação variada e de bom gosto. As pessoas portam-se naturalmente, como se estivessem em qualquer outro ambiente heterossexual, embora, sinta-se um clima de “paquera” no ar. Em alguns desses estabelecimentos os donos são homossexuais e, portanto, a casa acaba sendo voltada para o público GLBT, mesmo não sendo apenas estes, os freqüentadores.

Verificou-se que os lugares de “pegação” localizados próximo ao Conic são freqüentados pelo público masculino à noite e tem garotos de programa à espera dos clientes que chegam ao estacionamento para abordá-los. O valor do programa é variável. As saunas também são exclusivas para o público masculino e em geral com livre acesso para os rapazes de programa. A visita às saunas foi dificultada pelos atendentes, em respeito à privacidade dos freqüentadores. Foi observado que há a predominância de mulheres (lésbicas) nos cafés e de homens gays nas boates.

Quanto aos serviços ofertados, em alguns lugares há bom atendimento, sobretudo, naqueles que são administrados por gays ou lésbicas e que estão a mais tempo no mercado. Outros, porém, demonstram falta de profissionais habilitados para o atendimento conforme falado pelos próprios entrevistados, não há um treinamento profissional para os iniciantes, mesmo porque na contratação de garçons espera-se que os mesmos já tenham experiência anterior. O que se percebe, no entanto, é que embora tenha-se experiência no desenvolvimento da atividade, não se tem um preparo comportamental para atendimento ao público GLBT.

Este público é diferenciado e há necessidade de um atendimento específico. Como foi dito pelos gerentes entrevistados, existe apenas uma conversa franca quanto ao cliente que será 
atendido, para que não haja nenhuma demonstração de preconceito ou discriminação por parte do funcionário contratado. Tal iniciativa, embora informal, está de acordo com a teoria defendida por Beger apud OMT (1984 p.23), que considera a hospitalidade relevante para que o cliente sinta-se confortável e seguro.

Certamente que durante as visitas e entrevistas nestes lugares, não foi observado pela pesquisadora, nenhum comportamento anormal durante os serviços prestados pelos profissionais. Mesmo porque, presume-se até pelas entrevistas realizadas com o público GLBT, que o sentimento de satisfação ou insatisfação, conforto ou desconforto é algo que somente quem está em evidência, por ter um comportamento fora do que se estabelece de “padrão”, poderá transmitir o que é percebido no íntimo quando há um olhar preconceituoso, discriminatório, seja ele velado ou não.

Ao final deste trabalho constata-se, portanto, que não há satisfação total quanto aos lugares ofertados, sentimento gerado pela falta de atendimento qualificado e da falta de respeito que se verifica quando há a manifestação de trocas de carinhos entre os casais homossexuais. Percebe-se que o desrespeito social se dá por não conceber que há pessoas que optam por uma preferência sexual diferente. E de conformidade com Medeiros o aspecto mais sério do lazer é a liberdade que oferece ao indivíduo, ao qual permite experimentar-se, exprimir-se e, até, superar-se. É a necessidade de liberdade de expressão, tão mencionada pelos entrevistados.

Observa-se também que Brasília oferece uma infra-estrutura insuficiente para atender ao público GLBT. O número de estabelecimentos é ínfimo em relação ao mercado, precisando assim, de maiores investimentos no setor para atender esta crescente demanda, merecedora de uma prestação de serviços mais qualificados.

Para a satisfação do cliente, de acordo com Beni apud MOTA (1998 p.24), é necessário conhecer o consumidor, seus hábitos e preferências para melhor atendê-lo.

Esta pesquisa aponta que o mais importante não é criar lugares específicos para esse ou aquele, mas, adequá-los e qualificá-los de modo a estarem preparados para atender a todos os clientes incondicionalmente, proporcionando-lhes um sentimento de segurança e conforto, independente da preferência sexual. Mas, enquanto não for possível, que possa haver ambientes adequados ao público GLBT onde os mesmos sintam-se com liberdade para 
expressar as manifestações de afeto aos parceiros do mesmo sexo, sem passar por constrangimentos.

Este trabalho sugere a criação de parcerias entre os empreendedores e a oferta de cursos profissionalizantes disponíveis no mercado para oferecer qualificação aos profissionais que já trabalham ou desejam trabalhar em atendimentos específicos e segmentados, tais como GLBT, terceira idade, portadores de necessidades especiais, dentre outros para possibilitar a elevação do padrão de atendimento ao consumidor, conforme mencionado por Mota (2001 p.61).

Por fim, considera-se que a empresa que tem a visão do que representa o potencial desse segmento garantirá a qualidade no atendimento, superarando as expectativas do consumidor e conseqüentemente fidelizando-os. Para Trigueiro, (1999 p.57) a motivação para o lazer e turismo vem do atendimento às necessidades das pessoas. Se as mesmas têm satisfeitas suas expectativas, retornam várias vezes e fazem uma divulgação positiva, aumentando a demanda do local visitado. 


\section{REFERÊNCIAS BIBLIOGRÁFICAS}

ALMEIDA E CRILLANOVICK,Q. 50 Anos Depois: Relações Sociais e Grupos Socialmente Segregados. Goiânia,Ed. Cegraf/UFG. 2001

ANSARAH, M. G. R. e outros. Turismo - Como Aprender, Como Ensinar - Volume Dois. São Paulo: Senac, 2001.

AVIDOW, W. Serviço Total ao Cliente:A Arma Decisiva. Rio de Janeiro: Campus, 1991.

BENTO, B. A reinvenção do Corpo: Sexualidade e Gênero na experiência, Transexual, Tese de Doutorado/UNB, Brasília, 2003

INSTITUTO DE HOSPITALIDADE: Perfil dos profissionais no mercado de trabalho no setor de turismo no Brasil. Ed. Flash Design, Salvador, 2001.

CAVALCANTI, K. Esporte para todos: um discurso ideológico. Boletim de Intercâmbio. Rio de Janeiro, SESC,4 1983.

COBRA, M. Estratégia de Marketing de Serviços. São Paulo, Ed: Cobra, 2001

COOPER, C. OMT, Educando os Educadores em Turismo: Manual de Educação em Turismo e Hospitalidade. São Paulo, Ed. Roca, 2001

COSTA, M. Metodologia da Pesquisa: conceitos e técnicas. Rio de Janeiro: Interciência, 2001.

EMBRATUR: O Turismo na Economia Nacional : A Revolução Silenciosa, Ed. Letras, Brasileiras, 2001

FERREIRA, A. Dicionário Aurélio básico da língua portuguesa. Rio de Janeiro: Nova Fronteira, 1998

GOLIN E WEILER, Homossexualidades, cultura e política, Editora Sulina, Porto Alegre, 2002

HOUAISS, A. Dicionário Eletrônico HOUAISS da Língua Portuguesa, versão 1.0, Dezembro de 2001, Editora Objetiva Ltda.

KOTLER, P e ARMSTRONG, G. Princípios de Marketing. Trad. Vera Whateley. $7^{\text {a }}$ edição. Rio de Janeiro : LTC, 1995.

LDB - Brasil. Ministério da Educação. Educação Profissional - Legislação Básica. $5^{\circ}$ Edição, Brasília: MEC, 2001 
MARCELLINO,Nelson, Lazer e Educação, São Paulo, Ed. Papirus, 1987.

MICHAELIS, Pequeno Dicionário Michaelis, Inglês/Português, 1989.

MEDEIROS, E. O Lazer no Planejamento Urbano. Rio de Janeiro, Ed. Fundação Getúlio Vargas, 1975

MEDLIK E INGRAM, Introdução à Hotelaria - Gerenciamento e Serviços, Ed. Campus 2000

MOTA, K. Marketing Turístico: promovendo uma atividade sazonal. São Paulo: Atlas, 2001.

OLIVEIRA, A Turismo e Desenvolvimento: Planejamento e Organização. Ed. Atlas, São Paulo, 2001

OMT - Educando os Educadores em Turismo - Manual de Educação em Turismo e Hospitalidade. São Paulo, Ed. Roca, 2001

OMT - Introdução ao Turismo. Tradução: CORNER, Dolores Martin Rodriguez. São Paulo: Roca, 2001.

PARKER, R. Abaixo do Equador, São Paulo: Ed. Record, 2002.

PASCAL, B. Pensamentos, 2 Ed. São Paulo, D. Européia, 1961.

RAMIRES, L. Revista Extra G, julho de 2003.

RIOS, L. Revista Extra G, número 3, junho e julho de 2003, Associação Brasileira Interdisciplinar de AIDS.

ROSSI, L. Guia de Prevenção das DST/AIDS e Cidadania para Homossexuais, Ministério da Saúde, 2002.

SIQUEIRA, D. e BANDEIRA, L. 50 Anos Depois: Relações Sociais e Grupos Socialmente Segregados. Goiânia,Ed. Cegraf/UFG. 2001

STURBRIN, Homossexualidade, Ed. 1998

TREVISAN, J. Homossexualidade, Cultura e Política: A voz do desejo:Entre a autonomia e a cooptação. Ed. Sulina, Porto Alegre, 2002

TRIGUEIRO, C. Marketing e Turismo - Como Planejar e Administrar o Marketing Turístico para uma Localidade. Ed.Qualitymark, Rio de Janeiro , 2001

VIANA, F.V. Revista Brasília a Capital do Século 21

ZIMENEZ, M. Qualidade nos Serviços na Hotelaria. Ed. Universidade de São Paulo, 1999

MIRANDA, D. Câmara dos Deputados - Comissão de Direitos Humanos e Cidadania Homossexual $51^{\text {a }}$ Legislatura $-2^{\text {a }}$ Sessão Legislativa, Brasília, 2000 ,Centro de Documentação e Informação de Publicações 
Sites consultados na Rede Mundial de Computadores:

<www.aids.gov.br> Acessado em 19/09/03

$<$ www.estudosturisticos.com.br. Acessado em 25 de outubro de 2003.

$<$ www.hdn.com.br $>$ acessado em 15 de setembro de 2003

<www.observatoriobrasilia.org/materiais1.html> Acessado em 23 de fevereiro 2004.

<www.paroutudo.com> Acessado em 17 de Setembro de 2003.

Relatório Kinsey <www.jaimefarias.sites.uol.com.br> Acessado em 17 de setembro de 2003.

<www.rnmix.hpg.ig.com.br/canais/direito/leinatal.htm>Acessado em 24 de fevereiro de 2004 


\section{ANEXO A}

Questionário aplicado ao público GLBT

1- Dentre as opções de lazer que Brasília oferece ao público GLBT, quais o que você mais gosta?

2- Os lugares ofertados satisfazem as expectativas quanto à:

Privacidade

Atendimento

Localização

Preço

Segurança

3- Você considera importante um ambiente e serviços desenvolvidos para atender a grupos GLBT? Justifique:

4- Você se sente discriminado em ambientes heterossexuais?

5- Como seria um lugar ideal para você? 


\section{ANEXO B}

Roteiro de entrevista realizada com os proprietários de estabelecimentos GLBT

1. Qual a característica desse segmento (GLBT)?

2. Qual o marketing aplicado para atrair esse público?

3. Qual a estratégia específica para o atendimento desse público? 
ANEXO C 
ANEXO D 
ANEXO E 
ANEXO F 